\title{
The Exploring Research on Private University Political Instructor Team's Building Work
}

\author{
Chengsheng $\mathrm{Ma}^{1, \mathrm{a}}$ and Jingchao $\mathrm{Liu}^{2, \mathrm{~b}^{*}}$ \\ ${ }^{1,2}$ No.1 Xijing Road, Chang'an District, Xi'an City, Shaanxi Province, China \\ a179989455@qq.com, b805444342@qq.com
}

Keywords: Private university; Political instructor team; Higher education; Student work

\begin{abstract}
As part of the higher education, private colleges received more and more attention. Their teachers team construction is very important. The stand or fall of the political instructor team's construction related directly to the student management work. This paper studies on the problem. On the basis of practice, a lot of improvement measures are put forward.
\end{abstract}

\section{Introduction}

Xijing university is a private university that is approved by the ministry of education. In recent years, we have payed more attention to the political instructor team's construction, as an important content of party construction. As for perfecting the systems and mechanisms, strengthening the team management, the innovation and the working contents, gradually it become established an good political instructor team. The team has advanced ideas, prominent business capabilities. It's playing an important role in the following works: strengthen students' ideological and political work, regulate the routine education management of students, promote the students grow up in an all-round way[1].

\section{We Ensure the Clear Concept of the Construction Work, and at the Same Time Arrangement in Place}

As a private colleges, our students has its own characteristics. The students' composition is complex, and the comprehensive quality is uneven. Considering the situation, our school attaches the great importance to the counselors' teams construction, following the principle that "high into, selection, sympathetic, heavy culture". Through the practice, The counselor should makes himself to be the moral example of the students. At the same time, they should maintain physical and mental health, improve the art accomplishment of the guide of the coach, strengthen innovation ability. In the work practice, the political instructors and teachers team construction were build into the unified planning of the university[2]. And the stand or fall of the political instructor team's construction is an important standard of the university's leadership assessment. In recent years, our school continuously strengthen the system construction and standardized management, created a good atmosphere of respect the instructor work, respect the labor. All the measures eventually form the "attaches great importance to the party and government leadership, departments at all levels should" in the work situation[3].

\section{To Build up some Platforms, Boost the Professional Development of the Counselors}

Our school always adheres to the educational philosophy that "education, moral education first". The goal is building the high quality of counselor team that has "strong political, business, discipline strict, style", and boosting the professional development of the counselors[4].

Establishing the Platform's Organization, Leading the Professional Development of the Counselors Team. First, Set up the working group of the professionalization of counselor team. The headmaster and other managers are the team leaders of the working group and all employee join in to ensure the work. Second, establishing strict selection mechanism. Our school adhere to the principle that "the middle age, the secondary education, the member of Communist Party of China" 
in the recruitment process. Each instructor lead not more than 200 students. Third, building the counselor professionalization construction systems[5]. Eight professional teams are created to discuss and research the related work. Different team has different research content and direction to guarantees the integrity of the development of the team.

Building the Learning Platform, Improving the Level of Specialization of Counselors Professionalization. First, increasing the training investment. Each counselor has 2000 yuan training funds every year. And our school invest 100 ten thousand yuan to support the counselor to the study of colleges and universities at home and abroad such as Singapore Nanyang Polytechnic College. Second, widening the channel of the training. We not only send counselors to attend after-school training, but we also invite experts to do the training in our school. So far, our school has recommended 81 instructors to counselor counselor at or above the provincial level backbone training, invited experts, domestic masters do seminar[6]. Third, lay a solid theoretical foundation. The counselors completed a series of the theoretical and practical results, such as "Xijing university's counselors work case assembly". Fourth, strengthen professional skills training. In the past two years, more than 90 people attended the pre-service teachers' qualification training in theoretical knowledge, more than 50 people attended the counselor professional knowledge and skills training, and obtained the qualification certificate issued by the state. Five, encourage the counselors enhance the level of education. The school introduced various policies to guarantee it, such as: found the on-the-job graduate student education management workshops with the brother institutions, give subsidies to the employees of examination for graduate students, provide large amount of scholarships to the employees of examination for graduate students in our school.

Constructing Platform for Practicing, Improved the Comprehensive Ability of the Counsellors. First, strengthening practiced exercise outside. The school set up a multiple systems, such as good instructors credentials the exercise system, Internal rotational system, practice base exercise system. The systems ensure the target effectively that improve the comprehensive ability of the counselors. Second, focusing on jobs exercise. School puts forward higher and more detailed requirements on the counselor basic work. Counselors need to do eight things that to find a student talk every day, listen to the teacher once a week, held once a week class committee, a theme class meeting once a week, every two weekly diary notes a work, every two weeks, report the work to the competent leadership, Each semester reading a book about the student management work, Each semester write a paper about student work. If a counselor can stick to do this, his practice ability will be improved greatly. Beyond that, instructors can also through other ways to improve ability, such as work case competition, Blog contest, counselors occupational ability contest. Third, setting up the "academic advisor studio", "permanent mentors studio" etc. several instructors studio, established more than 10 special function centers that dominated by students of student work, for students to learn life, career guidance, career planning, provide close service to mental health consultation. Finally formed the good situation such as "Students can see teacher every day, Students can intimate conversation with the teacher, Upperclassman give the lower grade student experience, Academic advisor give students guidance in the class".

Establish the platform for teaching and scientific research, to promote the counselor team teaching scientific research level. Our school encourage counselors to lecture. The instructors can teach a series of courses such as "College students employment guidance, psychological health education, Careers and graduate employment, national defence education". These measurements enhance the expressiveness of the instructors and make them a lot of achievements in related fields, such as instructors subject, the ministry of education project, etc[7].

Setting up Incentive Platform, fully Arouse the Enthusiasm of the Counselor Creativity. First, introduced the counselor incentives that a counselor will be divided into different levels. School has established "the counselor professional ability level evaluation method". It divided counselors into different grades according to certain standards. These standards include degree, working hours, work performance, scientific research achievements, annual appraisal and so on. The counselor rating work conducted once a year. Each level can receive different subsidies, they are 100 yuan, 300 yuan, 600 yuan. Second, make sure that the Instructors can participate in the title 
evaluation and rating. Through the efforts, our school has a number of counselors promoted the senior titles. At the same time, there are many counselors promoted the medium level. Third, Ensure that the counselor can get more benefits that matching the job. From 2013, the school improve counselor post allowance from 2 yuan to 10 yuan per student. This ensures that the stability of the counselor team. Fourth, Outside of work, the school is also concerned about their life. The counselor who's family economic difficulties can get financial aid. The counselor's children can attend the remedial class that set up by school. Instructors can enjoy school meal allowance. Fifth, School promotes excellent counselor deeds to encourage other employees.

\section{Develop Characteristics of Subject Education, Broaden the Students' new Ways of Working}

The student management work is no longer rely on the management mode of college system, but in the dormitory system. Our school do this work since 2013. Unlike the traditional dormitory, now the dormitory has its own theme. For example, the business academy should build good business atmosphere, and the examination academy should build good study atmosphere. The atmosphere's build is based on the dormitory. A student dormitory will have different professional students, but they have the same hobby. The students can communicate with each other, and everyone can play to their specialty. Such education environment is more conducive to the growth of the students[8].

Outside environment, the education pattern has changed. The academy has professional instructors for the students in the academy's dormitory. Mentor into the dorms, increase the construction of study atmosphere. Students can be more convenient for guidance. It makes the better education effect.

The school focuses on training students' autonomous management consciousness. Students need to adapt to the society through the cultivation of independent consciousness. These students will get a better grades and will be more adaptable. In order to guarantee the effect of the reform, the school put the examination into the credit system. If get enough credit, students can graduate. If not, the opposite. The school make the cultivation more important that the feelings between teachers and students. It requires teachers to infinite care students and treat the students like they treat their children. At the same time, the teacher should also seize the students growing. Teachers and students make the growth plans together, then the teacher urge students to complete them. When students encounter problems, teachers offer the help. Such fine management ensures the students' healthy growth. In today's social background, the school also attaches great importance to the gratitude education[9].

\section{In the Process of Student Work, We also Found a lot of Problems. To Solve these Problems, We also Put forward some Suggestions}

Because of the particularity of working, the counselor's title can not be able to promotion. Counselors' work is hard to measure. They use a lot of time to deal with trivial but important things. More often, these things are breaking[10]. It will take up the main focus of the counselor. So, it is difficult for us to ask them to get high scientific research results. But this is the necessary material in promotion title. This would require the relevant departments to formulate corresponding policies to ensure the counselor's promotion. There are differences between the quality of the counselor of the private colleges and universities. This team is also very need professional training.

Integrated all of the above problems, we put forward the following Suggestions. First, the counselor training needs to strengthen, the number of people have been trained need to increase. Second, the counselor training needs the targeted curriculum system. The system will be established in accordance with the national standard. Third, we should clear the need of the counselor career ability and the details of the course system. Fourth, establish talent pool for the instructor. Cultivating excellent counselor make sure the sustainability of the team. Fifth, colleges and universities establish the counselor professional disciplines. 


\section{Summary}

Although, under our unremitting efforts, our students work has obtained certain achievement. But we also recognize that we need to continue to work hard. As a private college, there is a certain gap between long history school and us. The political education work need to strengthen. We will continue learn and progress to achieve a higher level.

\section{References}

[1] Benrong Liu. Private colleges and universities in the process of the transformation of development "double division type" the counselor team construction [J]. Journal of education observation (first half),2017,(02):64-65.

[2] Yue Wang. Based on the applied talents training run by the local college counselor team construction to explore [J]. Chinese training,2017,(04):3-5.

[3] Jianyong Shen. Promote private colleges counselors team work efficiency of the feasibility study [J]. Journal of HeNan education (higher education),2017,(02):99-100.

[4] Xiandong Zhang. College counselor team construction in the new period analysis [J]. Science Tribune (in the ten-day),2017,(01):16-17.

[5] Yuan Zhao,Tongguo Li. College counselors and ideological and political theory course teachers integrate research review [J]. Journal of LeShan teachers college journal,2017,(01):124-128.

[6] Zhenyue $\mathrm{Li}$. The fundamental path for the development of specialization and professionalization of college counselors team [J]. Journal of ideological education research,2013,(06):103-107.

[7] Xiang Liu. About the current college counselor team construction of thinking [J]. Journal of ideological and theoretical education Tribune,2013,(06):120-122.

[8] Xianjin Zhou,. The status quo of college counselor team construction and optimization idea - to 95 ordinary universities in HuNan province as the research object [J]. Journal of HuNan agricultural university (social science edition),2009,(04):54-59.

[9] Jin-xia Liang. Perfect the system Improve the mechanism for Promote healthy development of the counselor team, the national 103 college counselor team construction condition survey report [J]. Journal of national institute of education administration,2006,(06):83-88+82.

[10]Guorong Bie, a theory of higher education management power [J]. Journal of higher education research,2001,(02):36-39. 